Hybka M.M., Comparing efficiency of tax debt collection in Germany, Poland and the United Kingdom, „Ekonomia i Prawo. Economics and Law”, Polszakiewicz B., Boehlke J. (ed.), Vol. 14, No. 4/2015, pp. 427-442. DOI: http://dx.doi.org/10.12775/EiP.2015.028.

\title{
COMPARING EFFICIENCY OF TAX DEBT COLLECTION IN GERMANY, POLAND AND THE UNITED KINGDOM
}

\author{
SUMMARY
}

One of the most important determinants of the efficiency of tax revenue collection is the business cycle. Due to liquidity problems of entrepreneurs, increased tax evasion rates, decline in taxpayers' income and consumption an economic crisis may lead to substantial increase in tax arrears. In the European Union members states tax arrears pose more or less a problem for governments and tax authorities. According to the data presented by the Greek Ministry of Finance taxpayers' debt in Greece at the end of 2014 reached nearly 70 bln EUR. While the share of undisputed tax arrears in tax revenue collection equalled for this country in 2010 nearly $90.0 \%$ in such member states as Austria, Germany, Denmark it did not exceed 2.5\%. The article overviews the main indicators of the performance of tax debt collection in the European Union member states. The basic aim of this article is however to compare the stock and structure of tax debt and the efficiency of tax debt collection in Germany, Poland and the United Kingdom.

Keywords: tax debt; tax revenue collection; tax arrears; Germany; Poland; United Kingdom

JEL Classification: H20; H21; H60

"Małgorzata Magdalena Hybka, Poznań University of Economics, Faculty of Economics, Department of Public Finance, al. Niepodległości 10, 61-875 Poznań, Poland, phone: +48 6185438 64, e-mail: malgorzata.hybka@ue.poznan.pl. 


\section{INTRODUCTION}

The efficiency of tax debt collection is affected by a number of factors. Among them there are, inter alia, the administrative procedures of tax declaration, payment and enforcement. As far as the procedures of tax enforcement are concerned, a significant role is played by the means used to secure tax liabilities and recover tax debt.

The OECD systematically conducts research into tax collection performance in different countries, including the efficiency of tax debt recovery. These studies make it possible to compare the most important indicators of the performance of tax debt collection. They take into account not only the stock of tax arrears in particular years but also the amounts of tax debt recovered or written off.

Statistical data published by the OECD indicate that in the years 20052013 there was a significant increase of tax debt in its member states. In this period, the average relation of undisputed tax debt to tax revenue collection in all the OECD states rose from 9.8 to $21.5 \%$. However, there are significant discrepancies in the dynamics of this increase in particular member states.

This article compares the stock, structure and dynamics of tax debt and the efficiency of its recovery in Germany, Poland and the United Kingdom. The first part of the article includes also the characteristics of the most important indicators allowing to measure the efficiency of tax debt recovery and the analysis of the tax debt collection in selected EU member states. They include, inter alia, the following indicators: total tax debt as a share of tax revenue collection, non-collectible tax debt as a share of total tax debt, ratio of the number of tax debt cases at the beginning of the year to the number of tax debt cases at the end of the year, tax debt written off as a share of tax debt inventory.

\section{INDICATORS OF THE PERFORMANCE OF TAX DEBT COLLECTION IN THE EUROPEAN UNION MEMBER STATES}

The OECD publications take into account two categories of tax debt: disputed and undisputed. Disputed tax arrears (tax debt) cover (s) all the tax claims that are subject to dispute, objection or litigation. Undisputed tax debt (collectible tax debt) is defined as the total amount of tax (default interest included) that is overdue for payment at the end of the tax year and which is not disputed by the taxpayer ${ }^{1}$. Undisputed tax debt includes both the arrears

${ }^{1}$ M. Ebraico, S. Ruà, An Assessment of the Performance of the Italian Tax Debt Collection System, Office for Official Publications of the European Communities, Luxembourg 2015, p. 4. 
in relation to which enforcement proceedings have already started, and those in relation to which such proceedings have not yet been initiated. One of the indicators most often applied by the OECD, enabling to measure the extent of taxpayers' indebtedness is the relation of tax debt to net tax revenue collection (after deduction of tax refunds). For selected EU member states, this indicator is presented in table 1.

Table 1. Indicators of the performance of tax debt collection in selected EU member states (in \%)

\begin{tabular}{|c|c|c|c|c|c|c|c|c|}
\hline \multirow[t]{2}{*}{$\begin{array}{c}\text { EUROPEAN UNION } \\
\text { MEMBER STATE }\end{array}$} & \multicolumn{2}{|c|}{$\begin{array}{l}\text { TOTAL YEAR-END TAX } \\
\text { DEBT / NET REVENUE } \\
\text { COLLECTIONS FOR FI- } \\
\text { SCAL YEAR }\end{array}$} & \multicolumn{2}{|c|}{$\begin{array}{l}\text { UNDISPUTED TOTAL YE- } \\
\text { AR-END TAX DEBT / } \\
\text { NET REVENUE COLLEC- } \\
\text { TIONS FOR FISCAL YEAR }\end{array}$} & \multicolumn{2}{|c|}{$\begin{array}{l}\text { NON-COLLECTIBLE YE- } \\
\text { AR-END TAX DEBT / } \\
\text { TOTAL YEAR-END TAX } \\
\text { DEBT }\end{array}$} & \multicolumn{2}{|c|}{$\begin{array}{l}\text { NUMBER OF YEAR-END } \\
\text { TAX DEBT CASES / } \\
\text { NUMBER OF TAX DEBT } \\
\text { CASES AT YEAR BE- } \\
\text { GINNING }\end{array}$} \\
\hline & 2012 & 2013 & 2012 & 2013 & 2012 & 2013 & 2012 & 2013 \\
\hline Austria & 8.5 & 9.0 & 2.4 & 2.4 & 72.1 & 73.1 & 99.0 & 104.0 \\
\hline Belgium & 24.1 & 23.4 & 15.9 & 16.3 & 33.9 & 30.1 & 89.3 & 99.5 \\
\hline Czech Republic & $\mathrm{n} / \mathrm{a}$ & $\mathrm{n} / \mathrm{a}$ & 16.8 & 18.1 & $\mathrm{n} / \mathrm{a}$ & $n / a$ & 93.4 & 105.4 \\
\hline Denmark & 7.2 & 6.5 & $\mathrm{n} / \mathrm{a}$ & 4.9 & $n / a$ & 24.9 & 116.7 & 107.3 \\
\hline Estonia & 5.8 & 4.4 & $\mathrm{n} / \mathrm{a}$ & $n / a$ & $\mathrm{n} / \mathrm{a}$ & $\mathrm{n} / \mathrm{a}$ & 86.7 & 86.5 \\
\hline Finland & 8.2 & 7.4 & $\mathrm{n} / \mathrm{a}$ & n/a & $\mathrm{n} / \mathrm{a}$ & n/a & 111.8 & 105.1 \\
\hline France & 11.1 & 10.9 & 8.0 & 7.7 & 28.0 & 29.1 & 103.9 & 104.2 \\
\hline Germany & 3.2 & $\mathrm{n} / \mathrm{a}$ & 1.7 & $n / a$ & 46.3 & $\mathrm{n} / \mathrm{a}$ & 105.6 & $\mathrm{n} / \mathrm{a}$ \\
\hline Greece & 115.7 & 132.7 & $\mathrm{n} / \mathrm{a}$ & $n / a$ & $\mathrm{n} / \mathrm{a}$ & $\mathrm{n} / \mathrm{a}$ & 132.9 & 123.2 \\
\hline Hungary & 21.7 & 21.8 & 21.0 & 21.1 & 3.5 & 3.3 & 101.8 & 106.6 \\
\hline Ireland & 4.6 & 4.0 & 2.7 & 2.2 & 41.2 & 45.2 & $\mathrm{n} / \mathrm{a}$ & $\mathrm{n} / \mathrm{a}$ \\
\hline Italy & 229.5 & 257.0 & 169.6 & 190.8 & 26.1 & 25.8 & 108.7 & 108.4 \\
\hline Luxembourg & 15.8 & 15.0 & $n / a$ & n/a & $\mathrm{n} / \mathrm{a}$ & $\mathrm{n} / \mathrm{a}$ & 101.0 & 103.5 \\
\hline Netherlands & 6.9 & 6.6 & 3.8 & 3.8 & 44.9 & 42.2 & 107.1 & 93.3 \\
\hline Poland & 13.2 & 16.4 & 12.5 & 15.6 & 5.7 & 4.4 & $\mathrm{n} / \mathrm{a}$ & 102.5 \\
\hline Portugal & 35.7 & 31.7 & 26.0 & 24.2 & 27.2 & 23.7 & 99.8 & 124.5 \\
\hline Slovak Republic & $\mathrm{n} / \mathrm{a}$ & $\mathrm{n} / \mathrm{a}$ & 36.1 & 33.0 & $\mathrm{n} / \mathrm{a}$ & $\mathrm{n} / \mathrm{a}$ & 105.1 & 87.8 \\
\hline Slovenia & 14.7 & 14.0 & 9.9 & 8.6 & 32.8 & 38.8 & 49.0 & 169.2 \\
\hline Spain & 13.2 & 13.9 & $\mathrm{n} / \mathrm{a}$ & $\mathrm{n} / \mathrm{a}$ & $\mathrm{n} / \mathrm{a}$ & $\mathrm{n} / \mathrm{a}$ & $\mathrm{n} / \mathrm{a}$ & $\mathrm{n} / \mathrm{a}$ \\
\hline Sweden & 2.3 & 2.5 & $\mathrm{n} / \mathrm{a}$ & $n / a$ & $n / a$ & $\mathrm{n} / \mathrm{a}$ & 99.4 & 99.6 \\
\hline United Kingdom & 6.7 & 6.5 & 2.8 & 2.6 & 57.9 & 59.9 & $\mathrm{n} / \mathrm{a}$ & $\mathrm{n} / \mathrm{a}$ \\
\hline
\end{tabular}

Source: OECD, Tax Administration 2015: Comparative Information on OECD and Other Advanced and Emerging Economies, Paris 2015, p. 231; 233. 
Among the most indebted taxpayers in the European Union are those in Italy and Greece. Relatively insignificant are the tax arrears of taxpayers in Sweden. At the turn of 2012/2013 this relevant indicator increased in seven countries included in the table, to the greatest extent in Italy. In such countries as Austria or the United Kingdom, the share of non-collectible tax debt in the total of tax debt is relatively high. At the same time, in Hungary or in Poland, this indicator is relatively low. At the turn of 2012 and 2013, in nine of the countries included in the table, the relation of the number of year-end tax debt cases to the number of tax debt cases at the beginning of the year increased. In 2012, this indicator was the highest in Slovenia, Greece and Portugal.

In Poland, the share of tax debt written off to the total of tax debt is relatively low. At the same time, in Hungary, this indicator is relatively high, despite the low share of non-collectible tax debt in the total of tax debt. Apart from Hungary, other countries with the highest share of tax debt written off to tax debt inventory are Germany and the United Kingdom (figure 1).

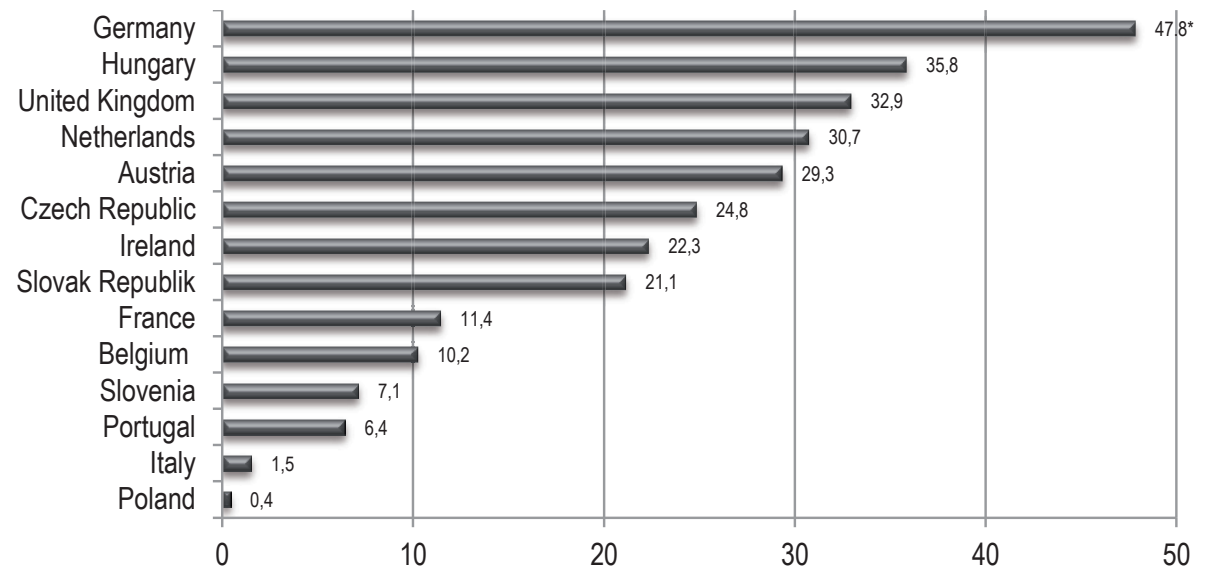

Figure 1. Tax debt written off as a share of tax debt inventory in selected EU member states at year beginning in 2013 (excluding disputed debt) (in \%)

* In the case of Germany, due to the lack of statistical data for 2013, the given values are for 2012. Source: OECD, Tax Administration 2015..., op. cit., p. 232.

\section{TAX DEBT COLLECTION IN GERMANY}

Germany belongs to a group of countries in which the stock of tax arrears is one of the lowest in the European Union. In 2012, the relation of the total of tax debt to tax revenue collection was lower only in Sweden. Figure 
2 shows that the share of undisputed tax debt in net tax revenue collection in 2005-2011 decreased from 1.8 to 1.3\%. Until 2012, the Federal Ministry of Finance published detailed statistical data concerning tax debt. These data included income tax, property tax and sales tax, but not municipal taxes, import VAT and excise duties.

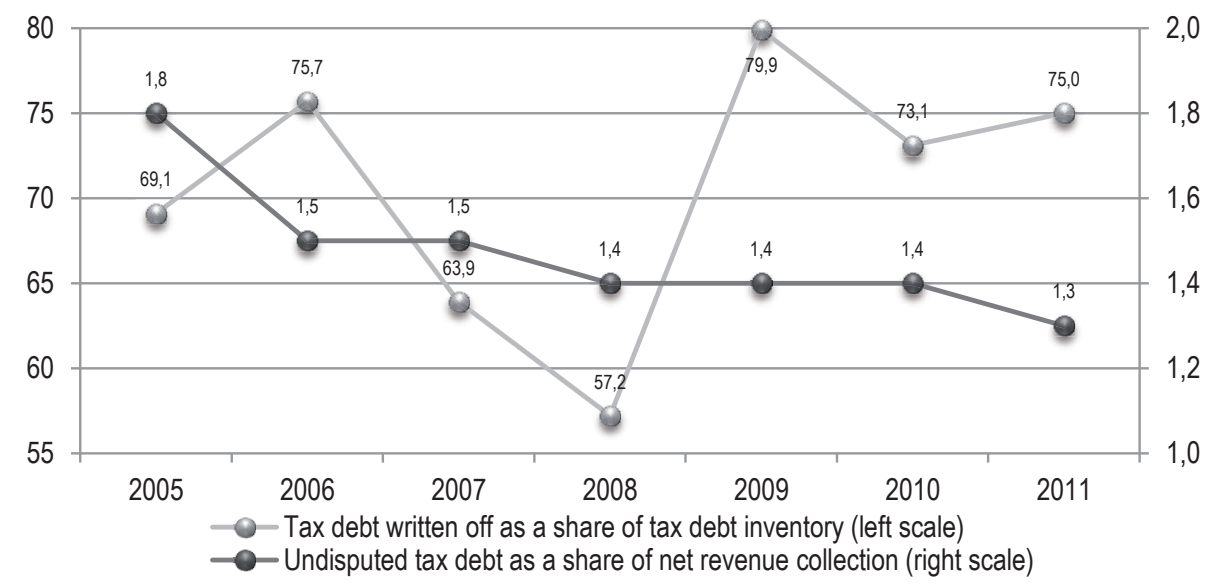

Figure 2. Selected indicators of the performance of tax debt collection in Germany in the years 20052011 (in \%)

Source: Own preparation based on: OECD, Tax Administration 2013: Comparative Information on OECD and Other Advanced and Emerging Economies, Paris 2013, pp. 222-224.

In Germany, the tax revenue comes predominantly from the personal income tax and the value added tax. The share of such taxes as: the assessed income tax and the wage withholding tax in the total of revenue collection in 2011 amounted to $30.2 \%$ and of the value added tax (excluding the import VAT) $-24.4 \%^{2}$. The data presented in table 2 show that in 2011, the share of tax revenue due from two most fiscally efficient taxes, i.e. the wage withholding tax and the value added tax in the total of tax revenue due, included for the purpose of tax debt statistics, equalled $72.7 \%$. Compared with the previous year, revenue due from most of the taxes listed in table 2 showed a rising tendency. One exception was the assessed income tax, in which case the revenue due decreased in 2011 in comparison with the previous year.

2 Bundesministerium der Finanzen, Kassenmäßige Steuereinnahmen nach Steuerarten in den Kalenderjahren 2010-2014, http://www.bundesfinanzministerium.de (16.09.2015). 
Table 2. Tax revenue due* and tax debt in Germany in 2011

\begin{tabular}{|c|c|c|c|c|c|c|c|}
\hline \multirow[b]{2}{*}{ TYPE OF TAX } & \multicolumn{3}{|c|}{$\begin{array}{c}\text { TAX REVENUE DUE AT THE END OF THE } \\
\text { YEAR }\end{array}$} & \multicolumn{3}{|c|}{ TAX DEBT AT THE END OF THE YEAR } & \multirow{2}{*}{$\begin{array}{c}\text { TAX DEBT } \\
\text { AS A SHARE } \\
\text { OF TAX } \\
\text { REVENUE DUE } \\
\text { (IN \%) }\end{array}$} \\
\hline & $\begin{array}{l}\text { MLN } \\
\text { EUR }\end{array}$ & $\begin{array}{l}2011 / 2010 \\
(\text { IN \%) }\end{array}$ & $\begin{array}{c}\text { SHARE } \\
\text { OF TOTAL } \\
\text { TAX REVENUE } \\
\text { DUE }(\text { IN \%) }\end{array}$ & $\begin{array}{l}\text { MLN } \\
\text { EUR }\end{array}$ & $\begin{array}{c}2011 / 2010 \\
(\text { IN \%) }\end{array}$ & $\begin{array}{c}\text { SHARE } \\
\text { OF TOTAL } \\
\text { TAX DEBT } \\
(\text { IN \%) }\end{array}$ & \\
\hline $\begin{array}{l}\text { Wage withhol- } \\
\text { ding tax }\end{array}$ & 176918 & 6.7 & 39.7 & 613 & 27.9 & 3.5 & 0.35 \\
\hline $\begin{array}{l}\text { Assessed inco- } \\
\text { me tax }\end{array}$ & 41140 & -0.8 & 9.2 & 7005 & -7.2 & 40.5 & 17.03 \\
\hline $\begin{array}{l}\text { Corporate in- } \\
\text { come tax }\end{array}$ & 18021 & 24.1 & 4.1 & 2087 & 3.6 & 12.1 & 11.58 \\
\hline $\begin{array}{l}\text { Value ad- } \\
\text { ded tax }\end{array}$ & 147018 & 1.8 & 33.0 & 4157 & -4.2 & 24.1 & 2.83 \\
\hline Other taxes & 62411 & 16.4 & 14.0 & 3425 & -34.1 & 19.8 & 5.49 \\
\hline Total & 445508 & 4.6 & 100.0 & 17287 & -11.7 & 100.0 & 3.88 \\
\hline
\end{tabular}

* Tax revenue due at the end of the year $=$ tax revenue collected + tax debt (tax arrears).

Source: Own preparation based on: Bundesministerium der Finanzen, Stand und Entwicklung der Steuerrückstande 2011, Berlin 2012, pp. 7-8.

In 2011, the greatest amount of tax debt was the assessed income tax debt and the value added tax debt. In 2011, their share in the total of tax debt equalled $64.5 \%$. In comparison with the previous years, the structure of tax debt according to the type of tax did not change. For example, in 2005, the share of debt from these two taxes in the total of tax debt equalled $65.4 \%{ }^{3}$. In the case of the assessed income tax, the relation of tax debt to the total of tax revenue due is high (table 2). This relation, however, decreased significantly when compared to 2005, when it amounted to $33.09 \%$. In 2011, in comparison to 2010 , tax debt decreased by $11.7 \%$.

As far as the relation of non-collectible tax debt to total tax debt is concerned, in 2012 Germany ranked third, after Austria and the United Kingdom. The data presented in figure 2 show also that in Germany the relation of tax debt written off to tax debt inventory is high. German tax law envisages a number of conditions in which tax debt may be remitted. In Germany, tax debt may, for example, be written off if the enforcement is ineffective, the taxpayer is in a difficult financial situation, or if there are other extraordinary cir-

${ }^{3}$ Bundesministerium der Finanzen, Stand und Entwicklung der Steuerrückstande 2005, Berlin 2006, pp. 5-6. 
cumstances, which the taxpayer could not have prevented, although he or she took all the available measures ${ }^{4}$.

\section{TAX DEBT COLLECTION IN POLAND}

The stock of tax arrears is in Poland distinctly higher than in Germany. Figure 3 shows that the share of undisputed tax debt in tax revenue collection rose in $2005-2011$ by as much as 10.3 percentage points. The greatest increase in this period took place between 2009 and 2010.

Tax revenue comes mainly from the value added tax and the personal income tax (table 3). In 2011, these taxes generated about $67.6 \%$ of the general budget tax revenue. However, the value added tax is also where the greatest tax debt occurs. In 2011 the share of arrears on this tax in total tax arrears amounted to as much as $52.6 \%$. The structure of tax debt has not changed significantly since 2005. Also in this year, the greatest amounts of tax arrears were arrears on the value added tax, whose share in total tax arrears amounted to $57.0 \%$.

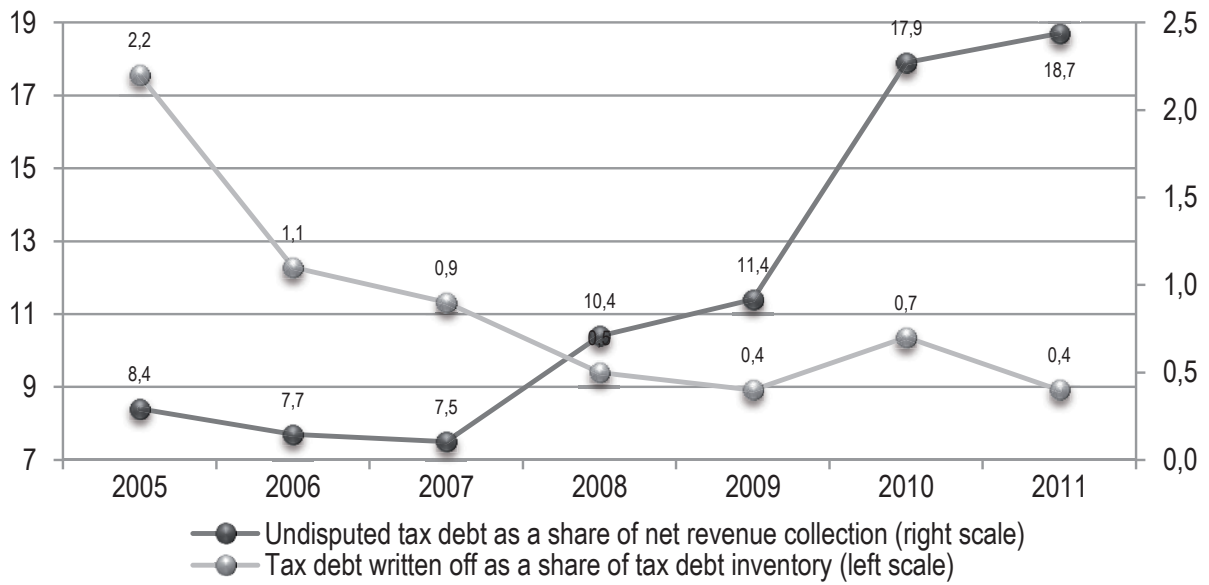

Figure 3. Selected indicators of the performance of tax debt collection in Poland in the years 2005-2011 (in \%)

Source: Own preparation based on: OECD, Tax Administration 2013..., op. cit., pp. 222-224.

${ }^{4}$ D. Dickertmann, Steuererbebung und Steuerrückstände, [in:] D. Bräunig (ed.), Stand und Perspektiven der öfentlichen Betriebswirtschaftslehre II, Festschrift für Prof. Dr. Dr. h.c. mult. Peter Eichhorn anlässlich seiner Emeritierung, Berliner Wissen-schafts-Verlag, Berlin 2007, pp. 3-7.

${ }_{5}^{5}$ Ministerstwo Finansów, Informacja o ksztattowaniu się zalegtości budizetowych z 2005 roku (Information on budgetary arrears from 2005), Warszawa 2006. 
Table 3. Tax revenue due* and tax debt in Poland in 2011

\begin{tabular}{|c|c|c|c|c|c|c|c|}
\hline \multirow[b]{2}{*}{ TYPE OF TAX } & \multicolumn{3}{|c|}{$\begin{array}{c}\text { TAX REVENUE DUE AT THE END OF THE YE- } \\
\text { AR }\end{array}$} & \multicolumn{3}{|c|}{ TAX DEBT AT THE END OF THE YEAR } & \multirow{2}{*}{$\begin{array}{c}\text { TAX DEBT } \\
\text { AS A SHA- } \\
\text { RE OF TAX RE- } \\
\text { VENUE DUE } \\
\text { (IN \%) }\end{array}$} \\
\hline & $\begin{array}{l}\text { MLN } \\
\text { PLN }\end{array}$ & $\begin{array}{l}2011 / 2010 \\
(\text { IN \%) }\end{array}$ & $\begin{array}{l}\text { SHARE OF TO- } \\
\text { TAL TAX RE- } \\
\text { VENUE DUE } \\
(\text { IN \%) }\end{array}$ & $\begin{array}{l}\text { MLN } \\
\text { PLN }\end{array}$ & $\begin{array}{l}2011 / 2010 \\
(\text { IN \%) }\end{array}$ & $\begin{array}{c}\text { SHARE } \\
\text { OF TOTAL } \\
\text { TAX DEBT } \\
(\text { IN \%) }\end{array}$ & \\
\hline $\begin{array}{l}\text { Personal in- } \\
\text { come tax }\end{array}$ & 72035 & 8.2 & 23.6 & 4530 & 11.2 & 17.9 & 6.29 \\
\hline $\begin{array}{l}\text { Corporate in- } \\
\text { come tax }\end{array}$ & 32996 & 13.8 & 10.8 & 1257 & 13.0 & 5.0 & 3.81 \\
\hline $\begin{array}{l}\text { Value ad- } \\
\text { ded tax }\end{array}$ & 134141 & 12.3 & 44.1 & 13309 & 14.6 & 52.5 & 9.92 \\
\hline Excise duties & 64120 & 4.5 & 21.0 & 6157 & 8.1 & 24.3 & 9.60 \\
\hline Other taxes & 1552 & -86.7 & 0.5 & 73 & 12.2 & 0.3 & 4.73 \\
\hline Total & 304845 & 5.8 & 100.0 & 25326 & 12.3 & 100.0 & 8.31 \\
\hline
\end{tabular}

* Tax revenue due at the end of the year $=$ tax revenue collected + tax debt (tax arrears).

Source: Ministerstwo Finansów, Informacja o kształtowaniu się zaległości budżetowych z lat 2010-2011 (Information on budgetary arrears from the years 2010-2011), Warszawa 2011-2012; Ministerstwo Finansów, Wpływy budżetowe w okresie od 01 stycznia 2010 roku do 31 grudnia 2010 roku oraz od 01 stycznia 2011 roku do 31 grudnia 2011 roku (Budgetary receipts in the period from January 1, 2010 to December 31, 2010 and from January 1, 2011 to December 31, 2011), Warszawa 2011-2012.

The share of tax debt in total of tax revenue in 2011 was the greatest in the case of the value added tax and the excise tax. When compared to 2005 , the share of the value added tax debt in the value added tax revenue decreased by about 2.7 percentage point, whereas the share of the excise tax debt in the excise tax revenue increased by about 2.5 percentage point.

Poland, as oppose to Germany, is a country in which the relation of noncollectible tax debt to total tax debt is exceptionally low. Among all the countries listed in table 1, this indicator was lower only in Hungary. At the same time, the relation of tax debt written off to total tax debt in 2005-2011 was very low and tended to decrease (figure 3). In Poland, the share of tax debt remitted to total tax debt is the lowest among the EU member states. In Poland, tax debt may be written off ex officio or on the request of the taxpayer if certain conditions are met (such as the important interest of the taxpayer or the public interest $)^{6}$. Detailed data from the Ministry of Finance reveal that in the general amount of tax arrears in 2011, about $56.5 \%$ was in enforcement proceedings.

${ }^{6}$ B. Adamiak et al., Ordynacja podatkowa. Komentarz 2014, Oficyna Wydawnicza „Unimex”, Wrocław 2014, p. 372. 


\section{TAX DEBT COLLECTION IN THE UNITED KINGDOM}

In the United Kingdom, the relation of the tax debt to tax revenue collection is lower than in Poland but higher than in Germany. In 2012 and 2013, among the EU member states, only in Austria, Ireland and Germany the share of undisputed tax debt in net tax revenue collection was lower than in the United Kingdom. In the United Kingdom, this share increased in the years 2008-2010, in 2011 and 2013 however decreased when compared to the previous year (figure 4). The comparison of statistical data concerning the performance of tax debt collection in the United Kingdom and other EU member states is made additionally difficult by the fact that the fiscal year in the United Kingdom is not the same as the calendar year (and lasts from April, $6^{\text {th }}$ of one year to April, $5^{\text {th }}$ of the following year).

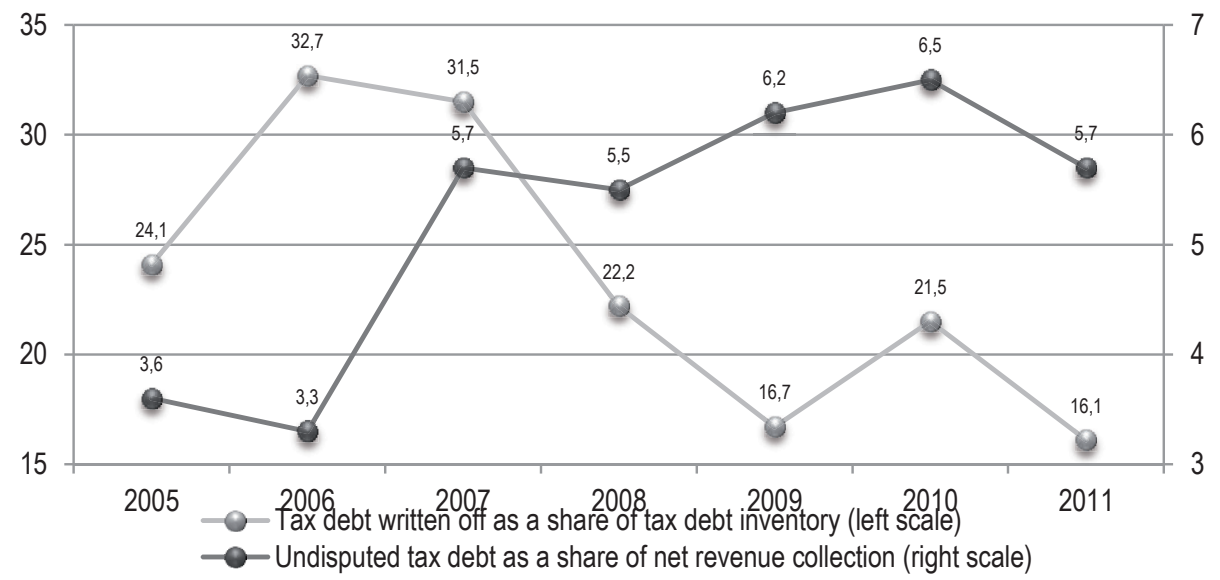

Figure 4. Selected indicators of the performance of tax debt collection in the United Kingdom in the years 2005-2011 (in \%)

Source: Own preparation based on: OECD, Tax Administration 2013..., op. cit., pp. 222-224.

From the data presented in table 4 it can be concluded that the basic source of HMRC receipts is income tax, whose share in tax revenue in the fiscal year of 2011/2012 amounted to $41.7 \%$ and in total HMRC receipts $32.5 \%$. The value added tax, whose share in tax revenue equalled 26.7 and in total HMRC receipts - 20.8\%, ranked second with respect to fiscal efficiency.

The greatest amounts of tax debt occur in the case of the income tax (figure 5). They concern the group of taxpayers using self-assessment. In the fiscal year of 2012/2013, the share of tax debt in this group of taxpayers in total debt owed to HMRC amounted to $26.2 \%$. Just as in Germany, debt is signif- 
icantly lower in the case of taxpayers paying withholding tax. In the United Kingdom, the system of tax credit contributes to significant overpayments and refunds, many of which are conferred in spite of their ineligibility, which contributes to tax debt, frequently categorised as non-collectible.

Table 4. Total HMRC receipts and tax debt in the United Kingdom in 2010/2011 and 2011/2012 (in bln GBP)

\begin{tabular}{|c|c|c|}
\hline SPECIFICATION & $2010 / 2011$ & $2011 / 2012$ \\
\hline Total HMRC receipts, including: & 453.6 & 472.3 \\
\hline- tax revenue, including: & 354.1 & 153.5 \\
\hline- income tax & 150.9 & 43.1 \\
\hline- corporation tax & 43.0 & 98.3 \\
\hline - value added tax & 83.5 & 17.9 \\
\hline Debt brought forward from prior year & 27.3 & 45.1 \\
\hline New debt created in-year & 15.0 & 63.0 \\
\hline Total debt managed in-year & 47.9 & 33.3 \\
\hline Devenue losses written-off and remitted & 62.9 & 5.5 \\
\hline
\end{tabular}

Source: HM Revenue \& Customs, HM Revenue and Customs Receipts, https://www.gov.uk (16.09.2015); National Audit Office, HM Revenue \& Customs 2011-12 Accounts. Report by the Comptroller and Auditor General, 2012, p. 29.

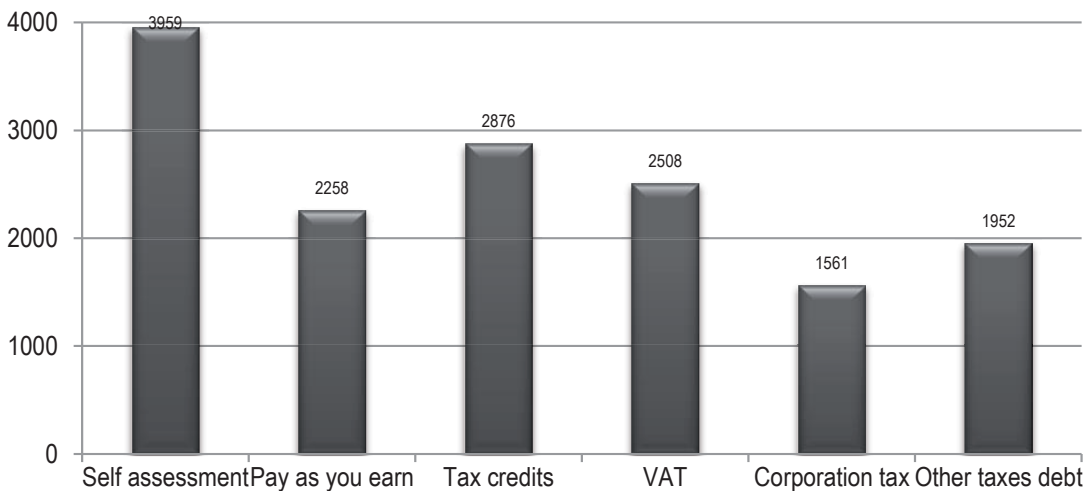

Figure 5. Tax debt owed to HMRC by type of debt as at 31 March 2013 (in mln GBP)

Source: National Audit Office, Managing debt owed to central government. Report by the Comptroller and Auditor General, London 2014, p. 14. 
The United Kingdom ranks second (after France) with respect to the relation of non-collectible tax debt to total tax debt. From the total amount of tax debt managed in 2010/2011 and 2011/2012, recovered was 56.6\%. About $8.5 \%$ of this debt was remitted. Irrecoverable tax debt may be written off because there is no practical way to pursue the tax liability, for example, when the taxpayer cannot be traced or has gone bankrupt ${ }^{7}$. HMRC may decide to remit the tax debt in the case of hardship or when the enforcement actions are unlikely to bring the amount exceeding the enforcement costs. The tax authorities may also reassess the tax liability, after having received additional information and as a result of this assessment cancel or amend the tax debt. Figure 4 shows that the greatest amounts of debt were written off in 2006 and 2007 (the OECD statistics takes into account tax debt remitted, written-off and cancelled or amended).

\section{FACTORS AFFECTING THE STOCK OF TAX ARREARS AND THEIR COLLECTION PERFORMANCE}

The stock of tax debt is determined by a number of factors of very diversified nature. These factors can be reviewed thanks to surveys conducted by the OECD in countries in which the scale of tax debt is insignificant. The results of this research indicates the significance of such determinants as: tax debt collection powers (including provisions making it possible to transfer the responsibility for tax liabilities to third parties and collect debt from third parties or regulations allowing for obtaining lien over the debtor's assets), the number and qualifications of tax debt collection staff, the use of information technologies in tax administration, including the implementation of electronic tax payment systems and electronic communication with tax authorities, or the number of withholding taxes and their application.

7 National Audit Office, HM Revenue E Customs 2011-12 Accounts. Report by the Comptroller and Auditor General, 2012, p. 28. 
Table 5. Enforced tax debt collection powers and tax debt collection staff in selected EU member states

\begin{tabular}{|c|c|c|c|c|c|c|c|}
\hline \multirow[b]{2}{*}{$\begin{array}{c}\text { EUROPEAN } \\
\text { UNION MEMBER } \\
\text { STATE }\end{array}$} & \multicolumn{6}{|c|}{ ENFORCED TAX DEBT COLLECTION POWERS (2011) } & \multirow[b]{2}{*}{$\begin{array}{c}\text { NUM- } \\
\text { BER OF TAX } \\
\text { DEBT COL- } \\
\text { LEC- } \\
\text { TION STAFF } \\
(2013)\end{array}$} \\
\hline & $\begin{array}{l}\text { GRANTING } \\
\text { FURTHER TI- } \\
\text { ME TO PAY }\end{array}$ & $\begin{array}{c}\text { COLLECTING } \\
\text { DEBT FROM } \\
\text { THIRD PAR- } \\
\text { TIES }\end{array}$ & $\begin{array}{c}\text { OBTAINING } \\
\text { LIEN OVER } \\
\text { ASSETS }\end{array}$ & $\begin{array}{l}\text { WITHHOL- } \\
\text { DING GO- } \\
\text { VERNMENT } \\
\text { PAYMENTS } \\
\text { TO DEBTORS }\end{array}$ & $\begin{array}{c}\text { RESTRICTING } \\
\text { OVERSEAS } \\
\text { TRAVEL BY } \\
\text { DEBTORS }\end{array}$ & $\begin{array}{c}\text { PUBLIS- } \\
\text { HING NAMES } \\
\text { OF DEBTORS }\end{array}$ & \\
\hline Austria & $x$ & $x$ & $x$ & $x$ & - & - & 780 \\
\hline Belgium & $x$ & $x$ & - & $x$ & - & - & $n / a$ \\
\hline Czech Republic & $x$ & $x$ & $x$ & - & - & - & 824 \\
\hline Denmark & $x$ & $x$ & $x$ & $x$ & $x$ & $x$ & 480 \\
\hline Estonia & - & $x$ & $x$ & - & - & $x$ & 99 \\
\hline Finland & $x$ & $x$ & $x$ & - & - & $x$ & 481 \\
\hline France & $x$ & $x$ & $x$ & $x$ & - & - & 6756 \\
\hline Germany & $x$ & $x$ & $x$ & $x$ & $x$ & - & 7560 \\
\hline Greece & $x$ & $x$ & $x$ & $x$ & - & $x$ & 800 \\
\hline Hungary & $x$ & $x$ & $x$ & $x$ & - & $x$ & 2727 \\
\hline Ireland & $x$ & $x$ & $x$ & $x$ & $x$ & $x$ & 822 \\
\hline Italy & $x$ & $x$ & $x$ & $x$ & $x$ & - & 900 \\
\hline Luxembourg & $x$ & $x$ & $x$ & $x$ & - & - & 168 \\
\hline Netherlands & $x$ & $x$ & $x$ & - & $x$ & - & 1542 \\
\hline Poland & $x$ & $x$ & $x$ & - & - & - & 5779 \\
\hline Portugal & $x$ & $x$ & $x$ & $x$ & - & $x$ & 1890 \\
\hline Slovak Republic & $x$ & $x$ & $x$ & - & - & - & 289 \\
\hline Slovenia & $x$ & $x$ & $x$ & $x$ & - & - & 437 \\
\hline Spain & $x$ & $x$ & $x$ & $x$ & - & - & 4421 \\
\hline Sweden & $x$ & $x$ & $x$ & - & - & - & $n / a$ \\
\hline United Kingdom & $x$ & $x$ & $x$ & - & - & - & 6409 \\
\hline
\end{tabular}

Source: OECD, Tax Administration 2015..., op. cit., p. 356; M. Ebraico, S. Ruà, An Assessment of the Performance of the Italian Tax Debt Collection System, Office for Official Publications of the European Communities, Luxembourg 2015, p. 22.

Some tax collection powers and some instruments for tax collection in selected EU member states are presented in table 5. Such instruments as restrictions on overseas travel in the case of bankruptcy and tax debt or publishing names of taxpayers in tax arrears are used only in few countries, others — such as collecting tax debt from third parties - are commonly applied. 
The list of factors affecting the stock of tax arrears analyzed in table 5 and presented in relative categories is not a complete list. Some of the important factors influencing the stock and structure of these arrears have been left out. The most important of them are reliability of taxpayers' documentation and statements, level of taxpayers' compliance when it comes to fulfilling payment obligations and especially their readiness to meet these obligations in due time. This readiness and reliability are many times higher in Germany and in the United Kingdom than in Poland and in turn they are many times higher in Poland than in such countries of southern Europe as Greece and Italy. The differences in this respect can result not only from the applied administrative procedures of collection of taxes, but also from taxpayers' mentality, which is influenced inter alia by historical factors ${ }^{8}$.

The stock of tax arrears is to a significant extent influenced by an economic situation. During a slowdown and in a period of recession, unemployment rises and so does the number of companies which go into bankruptcy and companies which lose their liquidity. Because of these reasons, the number of taxpayers who lose their ability to settle taxes in a timely manner rises, which leads to the increase in tax arrears. A reverse situation may be observed during an economic recovery and in a period of economic boom. In order to prevent the increase of tax arrears during an economic crisis tax authorities should apply proper administrative practices. According to J. Brondolo these practices include among others: development of the system of early detection of tax arrears and establishment of appropriate time standards for follow-up, maintenance of the quality and timeliness of tax arrears data, improvement of targeting enforcement efforts on recoverable arrears, introduction of the adequate procedures of remission of tax arrears deemed unrecoverable, implementation of the proper organizational and staffing arrangements for collection enforcement (including a greater organizational focus for large tax debts) or increase of the set of enforcement powers vested in tax administration ${ }^{9}$.

It can be seen from the data presented in the figures 2-4 that not in all studied countries did the financial crisis contribute to the growth of tax arrears. Despite this crisis the stock of tax arrears in Germany was decreasing. On the other hand, as a result of this crisis in Poland and to a lesser extent - in the United Kingdom, tax arrears increased.

${ }^{8}$ M. Alink, V. van Kommer, Handbook on Tax Administration, International Bureau of Fiscal Documentation, Amsterdam 2011, pp. 570-572.

9 J. Brondolo, Collecting Taxes during an Economic Crisis: Challenges and Policy Options, International Monetary Fund, Washington 2009, pp. 17-18. 
The stock of tax arrears also depends on the efficiency of the means used to secure the performance of tax obligations and on the procedures of recovery of tax arrears. This efficiency is unsatisfactory in Poland, while it is high in Germany and in the United Kingdom. Low efficiency of instruments of tax arrears securitization and execution in Poland is mainly caused by the fact that these instruments are not adjusted to modern market economy conditions. What is surprising - the share of non-collectible arrears in the totality of tax arrears in Poland is definitely lower than in Germany or in the United Kingdom. These arrears are defined as non-collectible mainly due to the fact that taxpayers who don't settle their tax obligations in time don't have sufficient sources of income and don't poses sufficient assets to successfully conduct execution. The stock of tax arrears is also influenced by another important factor of administrative nature. This factor is related to the institution of remission of tax arrears. As it has already been mentioned in chapter 1 of this article, during the years concerned the tax arrears were significantly more often remitted in Germany and in the United Kingdom than in Poland.

\section{CONCLUSIONS}

Comparing efficiency of tax collection among European Union member states is a complicated task. Its complexity results from the scarcity of statistical data and from different methods of their aggregation. This concerns also tax debt recovery. Indicators of the performance of tax debt collection published by the OECD give insight into the stock of tax debt but do not facilitate the analysis of its structure or the reasons for its formation.

Germany, Poland and the United Kingdom differ significantly with respect to efficiency of tax debt collection. In Germany, the stock of tax debt is low and systematically decreases, whereas in Poland, in 2008-2013 tax debt increased rapidly. In the United Kingdom, tax debt increased in the period of the financial crisis. However, in recent years, the share of undisputed tax debt in total revenue collection decreased. While in Germany and the United Kingdom tax debt arises mostly in the case of income tax and concerns income on which withholding tax is not imposed, in Poland, over a half of tax debt are arrears on the value added tax. In Germany and the United Kingdom, a significant part of tax debt is classified as non-collectible, whereas in Poland the percentage of non-collectible tax debt in total tax debt is insignificant. In Germany and the United Kingdom, a significant share of tax debt is written off, whereas in Poland remitted tax arrears do not 
exceed 1\%. The aforementioned facts may indicate that the performance of tax debt collection is more efficient in Germany and the United Kingdom than in Poland. However, the confirmation of this statement would require further and more detailed analysis, taking into account also enforcement proceedings applied in order to recover tax debt in particular countries.

\section{BIBLIOGRAPHY}

Adamiak B., Borkowski J., Mastalski R., Zubrzycki J., Ordynacja podatkowa. Komentarz 2014, Oficyna Wydawnicza „Unimex”, Wrocław 2014.

Alink M., van Kommer V., Handbook on Tax Administration, International Bureau of Fiscal Documentation, Amsterdam 2011.

Brondolo J., Collecting Taxes during an Economic Crisis: Challenges and Policy Options, International Monetary Fund, Washington 2009.

Bundesministerium der Finanzen, Kassenmäßige Steuereinnabmen nach Steuerarten in den Kalenderjahren 2010-2014, http://www.bundesfinanzministerium.de (16.09.2015).

Bundesministerium der Finanzen, Stand und Entwicklung der Steuerrückstande 2011, Berlin 2012.

Bundesministerium der Finanzen, Stand und Entwicklung der Steuerrückstande 2005, Berlin 2006.

Dickertmann D., Steuererhebung und Steuerrückstände, [in:] D. Bräunig (ed.), Stand und Perspektiven der öffentlichen Betriebswirtschaftslehre II, Festschrift für Prof. Dr. Dr. h.c. mult. Peter Eichhorn anlässlich seiner Emeritierung, Berliner Wissenschafts-Verlag, Berlin 2007.

Ebraico M., Ruà S., An Assessment of the Performance of the Italian Tax Debt Collection System, Office for Official Publications of the European Communities, $\mathrm{Lu}-$ xembourg 2015.

HM Revenue \& Customs, HM Revenue and Customs Receipts, https://www.gov. uk (16.09.2015).

Ministerstwo Finansów, Informacja o ksztattowaniu się zalegtości budżetowych z lat 2010-2011 (Information on budgetary arrears from the years 2010-2011), Warszawa 2011-2012.

Ministerstwo Finansów, Informacja o ksztattowaniu się zalegtości budżetowych z 2005 roku (Information on budgetary arrears from 2005), Warszawa 2006.

Ministerstwo Finansów, Wptywy budżetowe w okresie od 01 stycznia 2010 roku do 31 grudnia 2010 roku oraz od 01 stycznia 2011 roku do 31 grudnia 2011 roku (Budgetary receipts in the period from January 1, 2010 to December 31, 2010 and from January 1, 2011 to December 31, 2011), Warszawa 2011-2012.

National Audit Office, HM Revenue E Customs 2011-12 Accounts. Report by the Comptroller and Auditor General, 2012. 
National Audit Office, Managing debt owed to central government. Report by the Comptroller and Auditor General, London 2014.

OECD, Tax Administration 2013: Comparative Information on OECD and Other Advanced and Emerging Economies, Paris 2013.

OECD, Tax Administration 2015: Comparative Information on OECD and Other Advanced and Emerging Economies, Paris 2015. 